\title{
ANALISIS MIKROSTRUKTUR DAN SIFAT MAGNETIK TERHADAP PENGARUH SUHU SINTERING PADA YTTRIUM IRON GARNET DISINTESIS MENGGUNAKAN METODE SOLGEL
}

\section{PHASE AND MICROSTRUCTURE ANAL YSIS ON TEMPERATURE EFFECT OF YTTRIUM IRON GARNET SYNTHESIS USING SOL-GEL METHOD}

\author{
Sari Hasnah Dewi ${ }^{1,2}$, Ade Mulyawan ${ }^{2}$, Didin S. Winatapura ${ }^{2}$, Agustino Zulys ${ }^{1}$, dan \\ Wisnu Ari Adi ${ }^{2}$ \\ ${ }^{1}$ Departemen Kimia, Fakultas Matematika dan Ilmu Pengehuan Alam \\ Universitas Indonesia. Depok \\ ${ }^{2}$ Organisasi Riset Teknologi Nuklir, Badan Riset dan Inovasi Nasional \\ Gedung 43. Kawasan Puspiptek Serpong - Tangerang Selatan. \\ Telp : (021) 75874788 \\ E-mail : sari.analis@gmail.com
}

Diterima : $10-06-2021 \quad$ Direvisi : $11-11-2021 \quad$ Disetujui : $03-12-2021$

\begin{abstract}
ABSTRAK
Yttrium Iron Garnet (YIG), dengan formula umum $\mathrm{Y}_{3} \mathrm{Fe}_{5} \mathrm{O}_{12}$, merupakan kandidat material yang dapat digunakan sebagai komponen utama pada perangkat berbasis gelombang mikro. Untuk tujuan yang lebih khusus, YIG dapat dijadikan komponen utama dalam pembuatan bahan cat anti radar untuk perangkat alutsista militer. YIG memiliki karakteristik bahan yang sangat menunjang untuk tujuan ini seperti sifat magnetik dan elektromagnetik yang baik, konduktivitas termal yang baik, resistivitas listrik yang tinggi, dan nilai permittivitas yang tinggi. Pada penelitian ini, telah dilakukan proses pembuatan YIG menggunakan metode sol-gel auto combustion dengan variasi suhu sintering $900{ }^{\circ} \mathrm{C}$, $1100{ }^{\circ} \mathrm{C}$ dan $1300{ }^{\circ} \mathrm{C}$. Berdasarkan hasil analisis data X-ray diffractometer (XRD) menggunakan metode Rietveld dengan program General Structure Analysis System (GSAS), dapat diketahui bahwa fasa tunggal $\mathrm{Y}_{3} \mathrm{Fe}_{5} \mathrm{O}_{12}$ terbentuk pada suhu $1300{ }^{\circ} \mathrm{C}$. Hasil ini sesuai dengan analisis Thermogravimetry Analyzer (TGA) yang menunjukan bahwa pembentukan kristalit fasa $\mathrm{Y}_{3} \mathrm{Fe}_{5} \mathrm{O}_{12}$ terjadi pada suhu $1300-1400{ }^{\circ} \mathrm{C}$. Hasil data Fourier Transform Infra-Red (FTIR) menunjukkan terdapat puncak sistem tetrahedral garnet pada bilangan gelombang $670-560 \mathrm{~cm}^{-1}$. Struktur morfologi hasil observasi sampel menggunakan Scanning Electron Microscope (SEM) menunjukkan bahwa pada suhu sintering $1300{ }^{\circ} \mathrm{C}$ diperoleh tingkat homogenitas ukuran partikel yang paling tinggi dengan ukuran antara 1-2 $\mu \mathrm{m}$. Sifat kemagnetan menunjukan bahwa nilai saturasi magenetik tertinggi pada $\mathrm{Y}_{3} \mathrm{Fe}_{5} \mathrm{O}_{12}$ diperoleh pada sintering $1300{ }^{\circ} \mathrm{C}$ yaitu $20.75 \mathrm{emu} / \mathrm{g}$.

Kata kunci: fasa, metode sol-gel, struktur morfologi, yttrium iron garnet
\end{abstract}

\section{ABSTRACT}

Yttrium Iron Garnet (YIG), with the general formula $\mathrm{Y}_{3} \mathrm{Fe}_{5} \mathrm{O}_{12}$, is a candidate material used as the main component in microwave-based devices. For more specific purposes, YIG can be used as a significant component in manufacturing anti-radar materials for military defense equipment. YIG has characteristics supporting this purpose, such as good electromagnetic properties, good thermal conductivity, high electrical resistivity, and high permittivity values. This study carried out the YIG manufacturing process using the sol-gel auto combustion method with variations in sintering temperatures of $900{ }^{\circ} \mathrm{C}, 1100{ }^{\circ} \mathrm{C}$, and $1300{ }^{\circ} \mathrm{C}$. Based on the results of X-ray diffractometer (XRD) data analysis using the Rietveld method with the General Structure Analysis System (GSAS) program, it can be seen that the single-phase $Y_{3} \mathrm{Fe}_{5} \mathrm{O}_{12}$ is formed at a temperature of $1300{ }^{\circ} \mathrm{C}$. This result is under the Thermogravimetry Analyzer (TGA) analysis which shows that the formation of $Y_{3} \mathrm{Fe}_{5} \mathrm{O}_{12}$ phase crystallites occurs at a temperature of $1300-1400{ }^{\circ} \mathrm{C}$. The results of the Fourier Transform 
Infra-Red (FTIR) data show a peak garnet tetrahedral system at wave number $670-560 \mathrm{~cm}^{-1}$. The morphological structure of the sample observation using a Scanning Electron Microscope (SEM) shows that at a sintering temperature of $1300{ }^{\circ} \mathrm{C}$, the highest level of particle size homogeneity is obtained with a size between 1-2 $\mu \mathrm{m}$. The magnetic properties showed that the highest magnetic saturation value at $\mathrm{Y}_{3} \mathrm{Fe}_{5} \mathrm{O}_{12}$ was received at $1300{ }^{\circ} \mathrm{C}$ sintering, which was $20.75 \mathrm{emu} / \mathrm{g}$.

Keyword: morphology, phase, sol-gel method, Yttrium Iron Garnet

\section{PENDAHULUAN}

ahan smart-magnetik merupakan salah satu klasifikasi bahan maju yang di dalamnya mengandung kombinasi antara komponen oksida besi atau logam lainnya sehingga membentuk bahan kristal anorganik baru. Material jenis ini memiliki karakteristik nilai permeabilitas dan permitivitas yang baik sehingga dapat berinteraksi dengan gelombang elektromagnetik yang kompleks. Bahan smart-magnetik ini biasanya terdiri dari gabungan unsur logam tanah jarang dan logam transisi yang menghasilkan sifat magnetik yang dapat berfungsi sebagai bahan penyerap gelombang elektromagnetik (Winatapura et al 2020; Nimbore et al., 2006; Fisli et al., 2019; Mashadi et al., 2018). Garnet merupakan salah satu kandidat bahan smart-magnetik yang memiliki potensi luas untuk dimanfaatkan dalam berbagai aplikasi di bidang teknologi seperti bahan penyerap gelombang elektromagnetik, bahan sensor, dll ( Winatapura et al, 2020)

Yttrium Iron Garnet (YIG) atau dapat ditulis dengan $\mathrm{Y}_{3} \mathrm{Fe}_{5} \mathrm{O}_{12}$ merupakan tipe material garnet yang paling banyak digunakan untuk berbagai aplikasi di bidang teknologi diantaranya sebagai bahan frekuensi tinggi dan bahan penyerap gelombang elektromagnetik. Bahan garnet berbasis oksida besi dengan formula umum $\mathrm{A}_{3} \mathrm{Fe}_{5} \mathrm{O}_{12}(A=$ ion bervalensi +3 seperti $\mathrm{Y}^{3+}, \mathrm{Gd}^{3+}$, dII) memiliki tiga posisi sub-kisi kristalografi berbeda yaitu 16 ion $\mathrm{Fe}^{3+}$ pada sub-kisi oktahedral, 24 ion $\mathrm{Fe}^{3+}$ pada sub-kisi tetrahedral, dan 24 ion $\mathrm{Y}^{3+}$ pada sub-kisi dodekahedral. Hal ini yang menjadikan material garnet memiliki kestabilan tinggi disebabkan ion $\mathrm{Y}^{3+}$ hanya menempati posisi dodekahedral dan tidak mampu menempati posisi lain milik ion $\mathrm{Fe}^{3+}$ disebabkan perbedaan ukuran radius ionik yang besar antara kedua ion tersebut. Garnet juga diketahui memiliki karaketristik bahan yang baik diantaranya adalah sifat magnetik dan elektromagnetik yang baik, konduktivitas termal yang baik, resistifitas listrik yang tinggi, dan nilai permitivitas relatif yang tinggi (Ali et al., 2013; Akhtar et al., 2017; Sharma and Kuanr, 2018). Sifat magnetik pada bahan garnet dihasilkan dari interaksi super-exchange antara ion magnetik $\mathrm{Fe}^{3+}$ yang berada pada situs tetrahedral dan oktahedral.

Teknik preparasi adalah faktor penting dalam proses fabrikasi material $\mathrm{Y}_{3} \mathrm{Fe}_{5} \mathrm{O}_{12}$, hal ini berpengaruh pada homogenitas, sifat magnetik, fasa dan mikrostruktur dari material yang terbentuk. Suhu sintering atau suhu pemanggangan merupakan faktor utama dalam pembentukan bahan garnet. Proses sintering dalam fabrikasi material berbasis oksida besi melibatkan proses perubahan sebuah fasa nanokristalin menjadi fasa polikristalin padat. Dalam pengaruh suhu tinggi, area permukaan akan melalui pembentukan dan pertumbuhan ikatan antara partikel yang berasosiasi dengan proses reduksi dalam energi permukaan. Hal ini membuat partikel bergerak lebih dekat yang mengakibatkan penurunan porositas dan peningkatan densitas sampel.(Yehia et al., 2014; Azis et al., 2018; Shahrani et al., 2016). Pada studi yang telah dilakukan sebelumnya (Didin S. Winatapura, Ade Mulyawan, Wisnu A. Adi, 2020), walaupun telah dilakukan penelitian berbasis bahan $\mathrm{Y}_{3} \mathrm{Fe}_{5} \mathrm{O}_{12}$ namun $\mathrm{m}$ dilakukan studi secara terperinci mengenai efek suhu sintering terhadap proses pembentukan fasa, struktur morfologi, dan sifat magnetik. Oleh karena itu, dilakukan studi detil terkait pengaruh suhu sintering terhadap pembentukan fasa, perubahan struktur, morfologi permukaan, dan sifat magnetik bahan $\mathrm{Y}_{3} \mathrm{Fe}_{5} \mathrm{O}_{12}$.

Terdapat beberapa macam metode sintesis bahan yang dapat digunakan untuk 
membuat bahan $\mathrm{Y}_{3} \mathrm{Fe}_{5} \mathrm{O}_{12}$, diantaranya adalah metode sol-gel, metode reaksi padatan, dan metode microwave hydrothermal. Pada penelitian ini digunakan metode sol-gel untuk sintesis bahan $\mathrm{Y}_{3} \mathrm{Fe}_{5} \mathrm{O}_{12}$. Metode sol gel adalah teknik kimia basah yang secara luas telah digunakan dalam sintesis bahan garnet karena melibatkan temperatur yang rendah, tingkat pencampuran yang tinggi dan homogenitas yang lebih baik. Pada metode sol-gel pembentukan fasa yang stabil terbentuk pada suhu lebih rendah dibandingkan metode yang lain dan durasi sintering yang lebih singkat sehinga sifat magnetik tidak ter-reduksi. Pada penelitian sebelumnya, metode ini telah berhasil membuat fasa tunggal bahan NiLa ferit $\left(\mathrm{NiLaFe}_{2} \mathrm{O}_{4}\right.$ ) (Yunasfi, Mashadi and Mulyawan, 2017). Pada metode reaksi padatan, dimana bahan pembentuknya adalah serbuk oksida seperti $\mathrm{Y}_{2} \mathrm{O}_{3}$ dan $\mathrm{Fe}_{3} \mathrm{O}_{2}$, metode ini akan memakan waktu yang lama agar terbentuk bahan $\mathrm{Y}_{3} \mathrm{Fe}_{5} \mathrm{O}_{12}$ dengan rentang waktu puluhan jam dan durasi sintering panjang dan suhu yang tinggi hingga mencapai $1400{ }^{\circ} \mathrm{C}$. Selain itu selama proses milling rentan terkontaminsi impuritas karena gesekan dengan vial dari ball mill (Nimbore et al., 2006; Didin S. Winatapura, Ade Mulyawan, Wisnu A. Adi, 2020). Sedangkan metode microwave hydrothermal memperlukan reaksi kinetik yang lebih tinggi ditambah lagi add cost produksi yang tinggi (Ristić et al., 2003; Mathur et al., 2005; Aldbea, Ibrahim and Yahya, 2014; Musa et al., 2017; Simonenko et al., 2017; Rane et al., 2018; Zhen Yin Lau, Kean Chuan Lee, 2019; Parashar, Shukla and Singh, 2020). Pada penelitian awal ini, dilakukan studi perubahan mikrostruktur dan sifat magnetik dari pembentukan bahan $\mathrm{Y}_{3} \mathrm{Fe}_{5} \mathrm{O}_{12}$ terhadap pengaruh suhu sintering sintesis $\mathrm{Y}_{3} \mathrm{Fe}_{5} \mathrm{O}_{12}$. Oleh sebab itu, studi terkait pembentukan fasa, perubahan struktur, morfologi dan sifat magnetik sebagai dasar pertimbangan untuk memperoleh optimasi suhu sintering dalam proses sintesis bahan YIG akan dibahas pada makalah ini.

\section{METODE PENELITIAN Bahan dan Alat}

Yttrium nitrate hydrate $\left(\mathrm{Y}_{3}\left(\mathrm{NO}_{3}\right)_{3} \cdot 6 \mathrm{H}_{2} \mathrm{O}\right)$, iron (III) nitrate hydrate $\left(\mathrm{Fe}\left(\mathrm{NO}_{3}\right)_{3} 9_{2} \mathrm{O}\right)$, asam sitrat $\left(\mathrm{C}_{6} \mathrm{H}_{8} \mathrm{O}_{7} . \mathrm{H}_{2} \mathrm{O}\right)$, dan isopropanol $\left(\mathrm{C}_{3} \mathrm{H}_{8} \mathrm{O}\right)$ digunakan sebagai bahan prekursor untuk sintesis Yttrium Iron Garnet (YIG). Seluruh bahan menggunakan merk Sigma Aldrich dengan tingkat kemurnian diatas $99 \%$.

Alat yang digunakan dalam penelitian ini adalah alat-alat gelas, neraca analitis, mortar agate, magnetic stirrer, thermometer, oven, dan combustion boat. Instrumen yang digunakan untuk proses karakterisasi bahan adalah X-Ray Diffractiometer (XRD) untuk mengamati pembentukan fasa pada tiap sampel, Thermogravimetry Analyzer (TGA) untuk mengonfirmasi suhu sintering yang diperlukan untuk proses sintesis bahan, dan Scanning Electron Microscope (SEM) untuk mengamati morfologi sampel.

\section{Sintesis bahan $\mathrm{Y}_{3} \mathrm{Fe}_{5} \mathrm{O}_{12}$ (YIG)}

Bahan Yttrium nitrate hydrate $\left(\mathrm{Y}\left(\mathrm{NO}_{3}\right)_{3} \cdot 6 \mathrm{H}_{2} \mathrm{O}\right)$ dan iron (III) nitrate hydrate ( $\left.\mathrm{Fe}(\mathrm{NO} 3) 3.9 \mathrm{H}_{2} \mathrm{O}\right)$ ditimbang menggunakan neraca analitik berdasarkan perhitungan stoikiometri sesuai dengan reaksi berikut ini:

$$
3 \mathrm{Y}\left(\mathrm{NO}_{3}\right)_{3} \cdot 6 \mathrm{H} 2 \mathrm{O}+5 \mathrm{Fe}\left(\mathrm{NO}_{3}\right)_{3} \cdot 9 \mathrm{H}_{2} \mathrm{O} \rightarrow \mathrm{Y}_{3} \mathrm{Fe}_{5} \mathrm{O}_{12}
$$

Bahan yang sudah ditimbang kemudian dilarutkan dalam isopropanol. Campuran kemudian diaduk pada suhu $50{ }^{\circ} \mathrm{C}$ dengan magnetic stirrer di atas hot plate hingga larutan terbentuk. Kemudian ditambahkan larutan asam sitrat $\mathrm{C}_{6} \mathrm{H}_{8} \mathrm{O}_{7}$ (Mahendraprabhu and Elumalai, 2014) dalam asam nitrat dengan rasio 1:1 sebagai chelating agent dan bahan bakar pada proses combustion. 


$$
\text { Prekursor }\left[\mathrm{M}\left(\mathrm{C}_{6} \mathrm{H}_{8} \mathrm{O}_{7}\right)_{3}-\mathrm{x}\left(\mathrm{C}_{6} \mathrm{H}_{8} \mathrm{O}_{7}\right) \mathrm{x}\right]\left(\mathrm{M}=\mathrm{Fe}^{3+} \text { and } \mathrm{Y}^{3+}\right)
$$

Kemudian larutan dipanaskan hingga suhu $70{ }^{\circ} \mathrm{C}$ dan dilakukan pengadukan selama 15 menit hingga terbentuk gel berwarna coklat. Gel tersebut dipanaskan pada suhu $200-250{ }^{\circ} \mathrm{C}$ hingga kering sempurna. Pada saat pemanasan, gel mengembang dan kemudian terbakar secara spontan sehingga membentuk serbuk hijau gelap. Bubuk yang terbakar ditumbuk dan digerus menggunakan mortar untuk kemudian disinter dengan variasi suhu $900{ }^{\circ} \mathrm{C}, 1100{ }^{\circ} \mathrm{C}$ dan $1300{ }^{\circ} \mathrm{C}$ selama 4 jam.

\section{Karakterisasi Sampel}

Pengukuran difraksi sinar-X menggunakan alat $X$-ray diffractometer (XRD) PanAnalytical XD-610) dengan sumber $\mathrm{Cu}-\mathrm{Ka}$ pada panjang gelombang $(\lambda)=0,154 \mathrm{~nm}$ ). Plat yang berisi serbuk sampel diletakan pada holder sampel alat dan diukur pada rentang sudut $(2 \theta) 10^{\circ}-80^{\circ}$. Profil yang dihasilkan dari difraktometer sinar- $X$ dianalisis menggunakan metode Rietveld dengan bantuan program GSAS. Untuk karakterisasi menggunakan TGA, sampel serbuk ditimbang dan dimasukan ke dalam cawan alumina, kemudian pemanasan dilakukan hingga suhu $1500^{\circ} \mathrm{C}$ dengan kecepatan $10{ }^{\circ} \mathrm{C} /$ min karena pembentukan kristal garnet berlangsung dari suhu $900^{\circ} \mathrm{C}$ hingga $1300^{\circ} \mathrm{C}$ dengan menggunakan thermal analyzer dari Setaram Instrument. Spektrum infra-red (IR) untuk identifikasi gugus fungsi dan ikatan logam oksida diukur dengan alat Fourier Transformation Infra Red (FTIR) type Tensor 27 Bruker. Sampel dalam bentuk serbuk sebanyak $5 \mathrm{mg}$ dicampurkan dengan $\mathrm{KBr}$ kemudian digerus dan dihomogenkan lalu dipress membentuk pelet. Sampel diiradiasi dengan IR dalam rentang bilangan gelombang $500 \mathrm{~cm}^{-1}$ sampai $3000 \mathrm{~cm}^{-1}$. Karakterisasi SEM dilakukan untuk mengetahui morfologi, struktur mikro dan distribusi ukuran partikel dari sampel, pengujian dilakukan dengan perbesaran 5000 kali meggunakan alat SEM tipe JEOL JED-2300. Sifat magnetik bahan diidentifikasi dengan Vibration Sample Magnetometer(VSM)

\section{HASIL DAN PEMBAHASAN \\ Analisis Thermogravimetri (TGA)}

Dekomposisi termal bahan yang dihasilkan dari tahap auto-combustion dipelajari menggunakan Thermogravimetry Analyzer (TGA) seperti yang ditunjukan pada Gambar 1(a). Pada kurva TGA, terjadi 2 kali proses kehilangan berat yang signifikan yaitu pada rentang suhu $50-220^{\circ} \mathrm{C}$ sebesar $6 \%$ kemudian pada rentang suhu $220-800^{\circ} \mathrm{C}$ sebesar $8 \%$. Dekomposisi yang terjadi pada suhu dibawah $220{ }^{\circ} \mathrm{C}$ merupakan proses penghilangan air dalam prekursor gel. Kemudian dekomposisi dari asam sitrat, nitrat, dan sisa pembakaran lainnya terjadi pada suhu diatas $220^{\circ} \mathrm{C}$ hingga hilang sempurna pada suhu $800^{\circ} \mathrm{C}$. Kehilangan berat terakhir pada kurva TGA terjadi pada suhu $800^{\circ} \mathrm{C}$ yang merupakan titik awal kristalisasi fasa ortorombik $\mathrm{YFeO}_{3}$ yang kemudian diikuti dengan terbentuknya fasa dari $\mathrm{Y}_{3} \mathrm{Fe}_{5} \mathrm{O}_{12}$ pada suhu yang lebih tinggi. Pada perilaku dekomposisi termal yang berkaitan dengan efek eksotermik dan endotermik berdasarkan hasil pengukuran Differential Thermal Analysis (DTA) pada Gambar 1(b). Dapat kita lihat bahwa pada tahap pertama terdapat kurva endotermik antara $30-400^{\circ} \mathrm{C}$ dengan puncak pada $160^{\circ} \mathrm{C}$ yang dapat diinterpretasikan sebagai tahap penguapan air yang terserap dan pelarut lainnya. Untuk tahap selanjutnya, terdapat beberapa puncak kurva eksotermik yang secara jelas terlihat pada grafik dengan puncak berada pada suhu sekitar $472^{\circ} \mathrm{C}, 815^{\circ} \mathrm{C}$, dan $1220^{\circ} \mathrm{C}$. Pada posisi puncak eksotermik yang pertama, hal ini disebabkan oleh reaksi pembakaran dari nitrat dan asam sitrat. Sedangkan pada posisi puncak eksotermis yang kedua, hal ini disebabkan oleh mulai terbentuknya kristalit milik fasa $\mathrm{YFeO}_{3}$. Diatas suhu $900^{\circ} \mathrm{C}$, kurva DTA menjadi landai yang menandakan bahwa proses perubahan dari fasa $\mathrm{YFeO}_{3}$ menjadi fasa $\mathrm{Y}_{3} \mathrm{Fe}_{5} \mathrm{O}_{12}$ berlangsung pada daerah ini hingga akhirnya terbentuk puncak eksotermik yang ketiga pada posisi suhu 
$1220^{\circ} \mathrm{C}$. Suhu ini lebih rendah dari yang telah dilakukan oleh peneliti sebelumnya ( Winatapura et al 2020; Nimbore et al., 2006) yang masing-masing memerlukan suhu sintering mencapai suhu $1400^{\circ} \mathrm{C}$ dan $1300^{\circ} \mathrm{C}$. Oleh karena itu, dilakukan pengamatan mikrostruktur dan sifat magnetik pada proses sintering dengan rentang suhu tersebut yaitu suhu $900{ }^{\circ} \mathrm{C}, 1100{ }^{\circ} \mathrm{C}$ dan $1300{ }^{\circ} \mathrm{C}$.
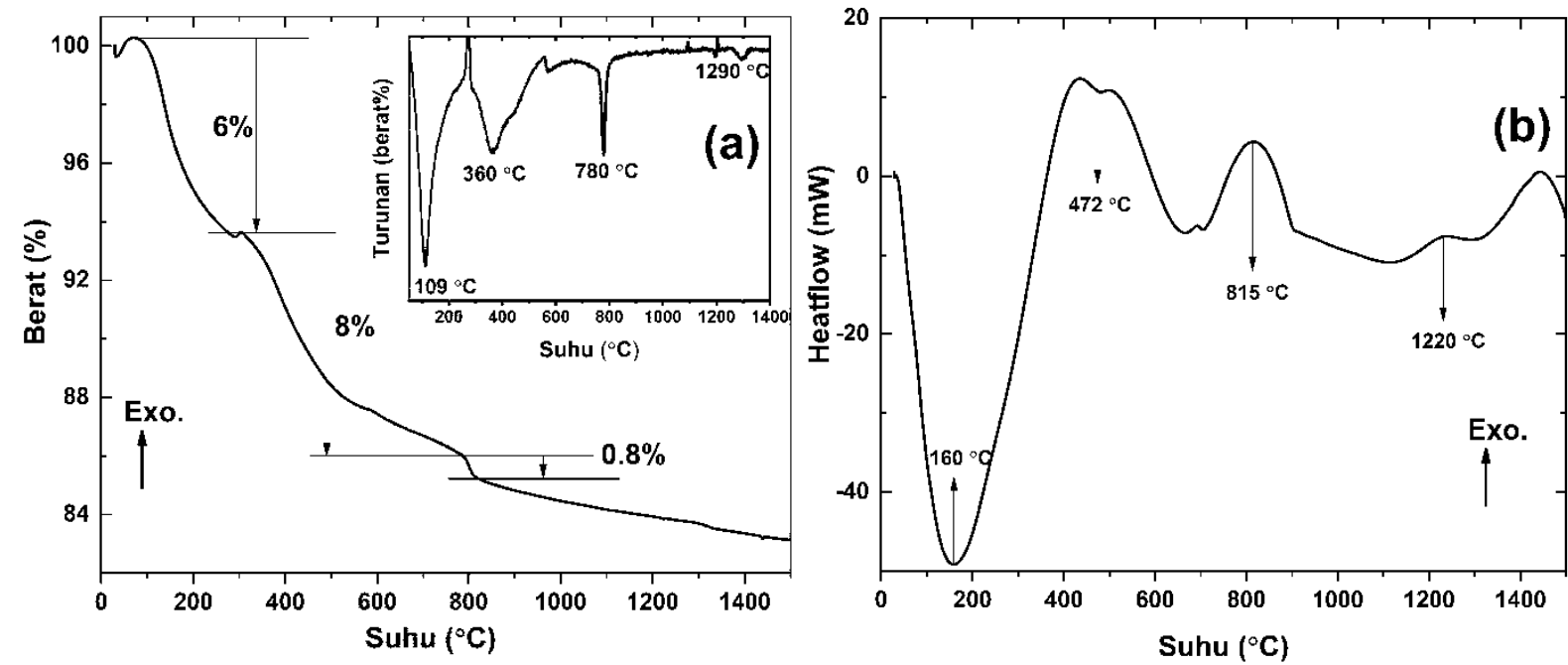

Gambar 1. Analisis TGA dan DTA hasil sintesis bahan menggunakan metode sol-gel auto combustion

\section{Analisis Pembentukan Fasa}

Untuk menentukan pembentukan fasa dari hasil variasi suhu sintering, dilakukan analisis pembentukan fasa menggunakan alat X-ray diffractometer (XRD). Gambar 2 menunjukan pola difraksi $\mathrm{Y}_{3} \mathrm{Fe}_{5} \mathrm{O}_{12}$ sebelum dilakukan proses sintering, dari gambar disimpulkan bahwa sebelum sintering belum terbentuk fasa yang kristalin dan masih bersifat amorf. Gambar 3 menunjukan pola difraksi $\mathrm{Y}_{3} \mathrm{Fe}_{5} \mathrm{O}_{12}$ dengan variasi suhu sintering $900^{\circ} \mathrm{C}$, $1100^{\circ} \mathrm{C}$ dan $1300^{\circ} \mathrm{C}$. Berdasarkan hasil penyesuaian fasa antara hasil eksperimen dengan data referensi kristal, dapat diketahui bahwa pada sampel $\mathrm{T}=900^{\circ} \mathrm{C}$ fasa $\mathrm{Y}_{3} \mathrm{Fe}_{5} \mathrm{O}_{12}$ (ICCD dengan kode 961008629) telah terbentuk namun masih terkandung fasa pengotor lain milik fasa $\mathrm{YFeO}_{3}$ (ICDD dengan kode 962101387). Hal yang sama pun ditemukan pada sampel $\mathrm{T}$ $=1100^{\circ} \mathrm{C}$ dimana mayoritas puncak dapat terindeks dengan bidang kristal milik $\mathrm{Y}_{3} \mathrm{Fe}_{5} \mathrm{O}_{12}$ fasa namun masih terdapat fasa milik $\mathrm{YFeO}_{3}$. Pada sampel $\mathrm{T}=1300^{\circ} \mathrm{C}$, hanya terdapat fasa tunggal milik fasa $\mathrm{Y}_{3} \mathrm{Fe}_{5} \mathrm{O}_{12}$.

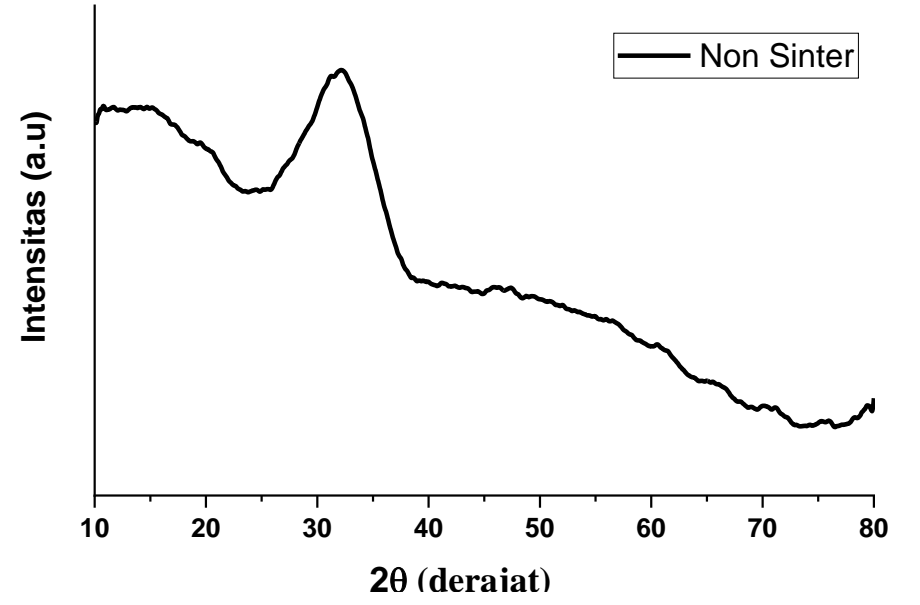

Gambar 2. Pola difraksi $\mathrm{Y}_{3} \mathrm{Fe}_{5} \mathrm{O}_{12}$ sebelum sintering 


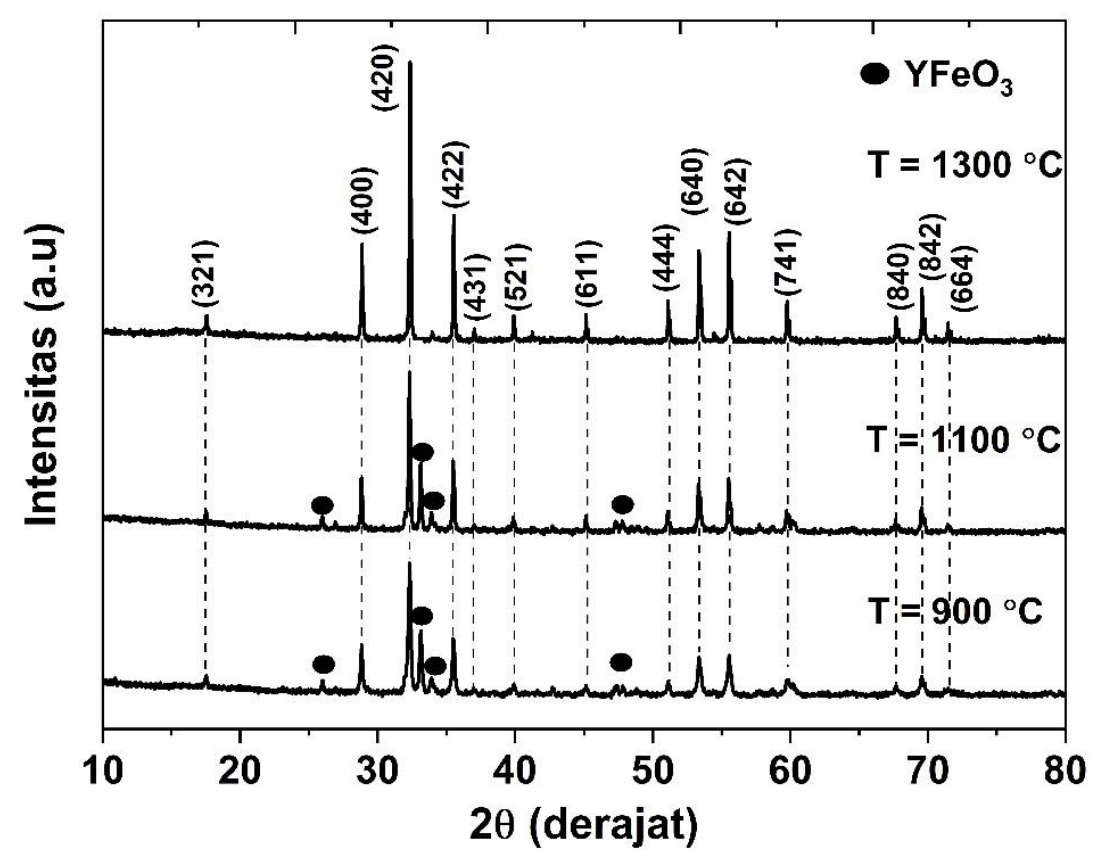

Gambar 3. Pola diffraksi sampel dengan variasi suhu sintering $900^{\circ} \mathrm{C}, 1100{ }^{\circ} \mathrm{C}$ dan $1300^{\circ} \mathrm{C}$

Hal ini menunjukan bahwa sampel dengan komponen fasa tunggal telah berhasil didapatkan. Pola difraksi untuk sampel $\mathrm{T}=1300^{\circ} \mathrm{C}$ juga memiliki intensitas relatif yang lebih tinggi dibandingkan dengan kedua sampel yang lain seperti yang ditunjukkan pada puncak khas bahan garnet yakni pada posisi difraksi bidang (400), (420), dan (422). Hal ini menunjukan bahwa sampel memiliki derajat kristalinitas yang lebih tinggi yang disebabkan oleh fasa tunggal $\mathrm{Y}_{3} \mathrm{Fe}_{5} \mathrm{O}_{12}$ sudah terbentuk sempurna. Pola puncak difraksi yang sama juga didapatkan pada penelitian yang lain (Nimbore et al., 2006; Didin S. Winatapura, Ade Mulyawan, Wisnu A. Adi, 2020). Merujuk kembali kepada data TGA/DTA, terdapat kesesuaian antara hasil pembentukan fasa dengan analisis dekomposisi termal yang menunjukkan bahwa kristalisasi sempurna untuk fasa $\mathrm{Y}_{3} \mathrm{Fe}_{5} \mathrm{O}_{12}$ berada pada suhu sintering sekitar $1300^{\circ} \mathrm{C}$. Untuk menentukan persentase fasa yang terbentuk pada seluruh sampel yang telah dibuat, dilakukan analisis lebih dalam terhadap hasil data XRD yakni dengan melakukan proses refinement dengan bantuan program GSAS.

Tabel 1. Hasil refinement seluruh sampel dengan variasi suhu sintering $900^{\circ} \mathrm{C}, 1100{ }^{\circ} \mathrm{C}$ dan $1300^{\circ} \mathrm{C}$

\begin{tabular}{|c|c|c|c|c|c|c|c|}
\hline \multirow[b]{2}{*}{ Sampel } & \multirow[b]{2}{*}{ Fasa } & \multirow{2}{*}{$\begin{array}{l}\text { kisi }(\AA) \\
a=b=c\end{array}$} & \multirow{2}{*}{$\begin{array}{c}\text { Volume } \\
\left(\AA^{3}\right)\end{array}$} & \multirow{2}{*}{$\begin{array}{c}\text { Fraksi } \\
\text { (berat\% } \\
\text { ) }\end{array}$} & \multicolumn{2}{|c|}{ Faktor-R } & \multirow[b]{2}{*}{$x^{2}$} \\
\hline & & & & & $\begin{array}{c}R_{\text {up }} \\
(\%)\end{array}$ & $\begin{array}{c}R_{\mathrm{p}} \\
(\%)\end{array}$ & \\
\hline \multirow{2}{*}{900} & $\mathrm{Y}_{3} \mathrm{Fe}_{5} \mathrm{O}_{12}$ & 12,358 & 1887,518 & 68,00 & \multirow{2}{*}{5,82} & \multirow{2}{*}{4,72} & \multirow{2}{*}{1,36} \\
\hline & $\mathrm{YFeO}_{3}$ & $5,577=7,59=5,28$ & 223,571 & 32,00 & & & \\
\hline \multirow{2}{*}{1100} & $\mathrm{Y}_{3} \mathrm{Fe}_{5} \mathrm{O}_{12}$ & 12,3799 & 1897,379 & 70,00 & \multirow{2}{*}{4,63} & \multirow{2}{*}{3,49} & \multirow{2}{*}{1,70} \\
\hline & $\mathrm{YFeO}_{3}$ & $5,57=7,58=5,26$ & 222,71 & 30,00 & & & \\
\hline \multirow{2}{*}{1300} & $\mathrm{Y}_{3} \mathrm{Fe}_{5} \mathrm{O}_{12}$ & 12,361 & 1888,705 & 100,00 & \multirow{2}{*}{4,09} & \multirow{2}{*}{3,12} & \multirow{2}{*}{1,73} \\
\hline & $\mathrm{YFeO}_{3}$ & - & - & & & & \\
\hline
\end{tabular}


Proses refinement dilakukan dengan membandingkan data referensi dengan eksperimen, adapun kualitas dari proses refinement ditentukan oleh dua faktor yakni nilai criteria of fit (faktor R) dan goodness of fit (faktor $\chi^{2}$ ). Proses refinement dikatakan memiliki kualitas yang baik jika selisih nilai antara $R_{u p}$ dan $R_{\mathrm{p}}$ kurang dari $2 \%$ serta nilai goodness of fit (faktor $\chi^{2}$ ) yang mendekati nilai yang dapat diterima.

Gambar 3 menunjukkan hasil proses refinement menggunakan metode Rietveld untuk

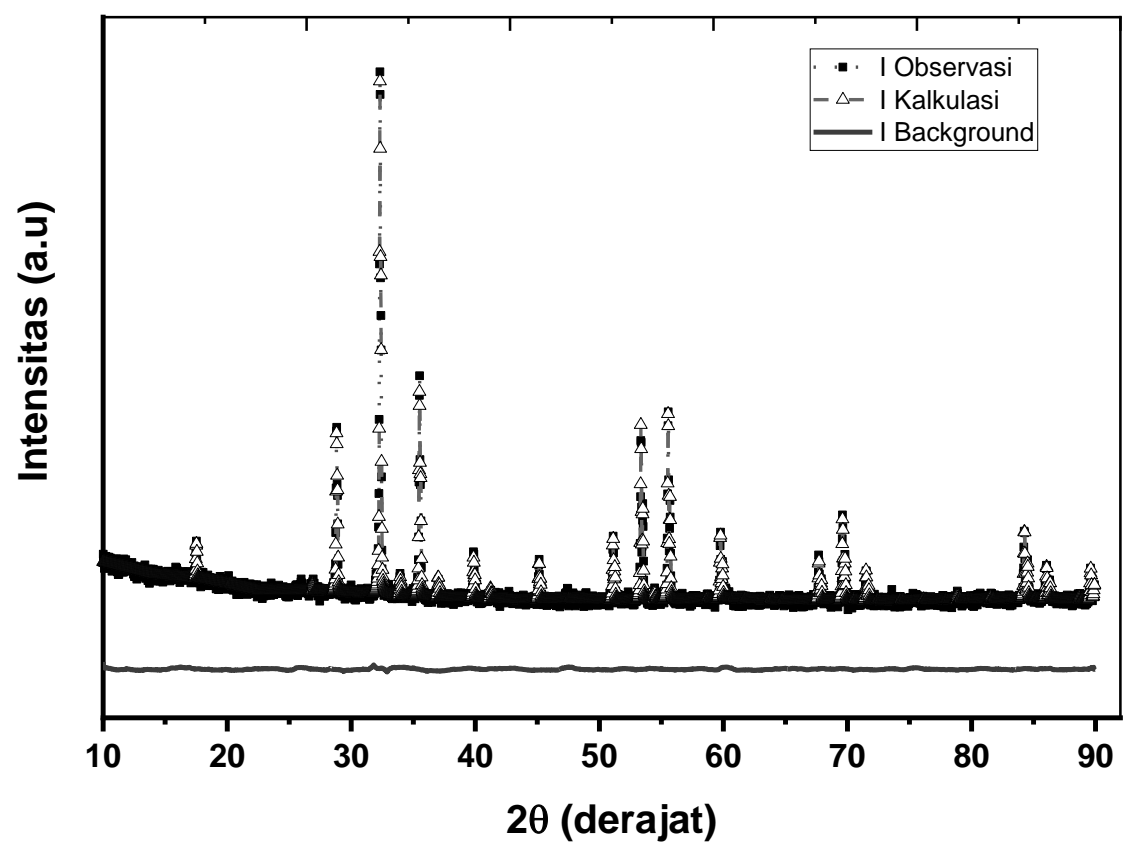

Gambar 4. Grafik hasil proses refinement untuk sampel dengan suhu sintering $1300{ }^{\circ} \mathrm{C}$

sampel $\mathrm{T}=1300{ }^{\circ} \mathrm{C}$. Hasil analisa lengkap proses refinement ditampilkan pada tabel 1 . Dengan melihat grafik pada proses refinement yang diwakilkan oleh sampel $\mathrm{T}=1300^{\circ} \mathrm{C}$ dan data pada tabel 1 , dapat kita simpulkan bahwa hasil refinement memiliki kualitas yang baik merujuk pada nilai $\chi^{2}$ yang mendekati nilai yang dapat diterima dan selisih nilai $R_{m p}$ dan $R_{\mathrm{p}}$ kurang dari $2 \%$. Pada sampel $\mathrm{T}=900^{\circ} \mathrm{C}$, persentase fraksi berat (\%berat) untuk fasa $\mathrm{Y}_{3} \mathrm{Fe}_{5} \mathrm{O}_{12}$ adalah $68 \%$ sedangkan untuk fasa $\mathrm{YFeO}_{3}$ adalah $32 \%$. Dengan meningkatnya suhu sintering menjadi $1100{ }^{\circ} \mathrm{C}$ mampu meningkatkan fraksi berat fasa $\mathrm{Y}_{3} \mathrm{Fe}_{5} \mathrm{O}_{12}$ menjadi 70 $\%$ hingga pada akhirnya terbentuk komponen fasa tunggal $\mathrm{Y}_{3} \mathrm{Fe}_{5} \mathrm{O}_{12}$ saat sintering sekitar $1300^{\circ} \mathrm{C}$. Ukuran parameter kisi juga mengalami perubahan seiring dengan perubahan suhu sintering, ukuran kisi fasa $\mathrm{Y}_{3} \mathrm{Fe}_{5} \mathrm{O}_{12}$ (struktur kristal kubik, dengan grup ruang Ia-3d) pada sampel $\mathrm{T}=1100^{\circ} \mathrm{C}$ lebih besar dibandingkan sampel $\mathrm{T}=900^{\circ} \mathrm{C}$ dikarenakan berkurangnya fasa pengotor milik $\mathrm{YFeO}_{3}$ dan pengaruh difusi akibat suhu sintering. Pada sampel $\mathrm{T}=$ $1300^{\circ} \mathrm{C}$, ukuran kisi semakin kecil sebagai kompensasi regangan kisi yang berkurang akibat hanya terdapat satu fasa penyusun pada sampel ini .

Untuk memastikan pembentukan fasa $\mathrm{Y}_{3} \mathrm{Fe}_{5} \mathrm{O}_{12}$ dan mempelajari mode vibrasi yang terjadi, dilakukan analisa Fourier Transform Infra-Red (FTIR). Gambar 4 menunjukkan spektrum FTIR milik sampel dengan variasi suhu sintering. Pada gambar (a) menunjukan serapan IR pada sampel yang belum disintering, dari gambar terlihat bahwa ada serapan yang tajam pada bilangan gelombang $2400 \mathrm{~cm}^{-1}$ yang merupakan milik dari mode stretching $\mathrm{O}-\mathrm{H}$ dari golongan karboksilat yang berasal dari asam sitrat. Dan pada bilangan gelombang $1400 \mathrm{~cm}^{-1}-1625 \mathrm{~cm}^{-1}$ terdapat serapan yang sangat lebar untuk vibarasi $\mathrm{C}=\mathrm{O}$ stretching dan $\mathrm{O}-\mathrm{H}$ bending, hal ini menunjukan kelembaban yang tinggi dari sampel karena belum disintering dan memiliki serapan yang lebar dari bilangan gelombang $500-700 \mathrm{~cm}^{-1}$ yang 
merupakan serapan vibarasi ikatan unsur metal (O-M) dengan oksigen yang belum tajam sehingga belum terdiferensiasi dan mendukung hasil difraksi XRD bahwa fasa amorf karena belum ada ikatan kristalin yang solid di dalam sampel. Selanjutnya untuk serapan Gambar (b) suhu sintering $900^{\circ} \mathrm{C}$ dan $1100^{\circ} \mathrm{C}$ besarnya serapan untuk vibarasi $\mathrm{O}-\mathrm{H}$ dan $\mathrm{C}-\mathrm{O}$ mulai berkurang dan ikatan vibarasi O-M mulai tajam yang menunjukan bahwa telah terbentuk ikatan O-M yang lebih kuat di dalam sampel. Sedangkan pada gambar (c) serapan untuk faktor kelembaban telah berkurang secara signifikan dan serapan untuk vibrasi O-M sangat tajam. Spektrum FTIR pada suhu sintering $1300^{\circ} \mathrm{C}$ menunjukkan pita serapan (absorbance band) pada posisi bilangan gelombang $610 \mathrm{~cm}^{-1}$ dan $765 \mathrm{~cm}^{-1}$. Kedua mode yang terbentuk ini merupakan mode khas yang dimiliki oleh struktur garnet yang berasal dari vibrasi ikatan antara kation logam dan ion oksigen pada kisi tetrahedral. Pita serapan yang terletak pada posisi bilangan gelombang $900 \mathrm{~cm}^{-1}$ merupakan mode regangan (stretching mode) dari senyawa $\mathrm{NO}_{3}$.
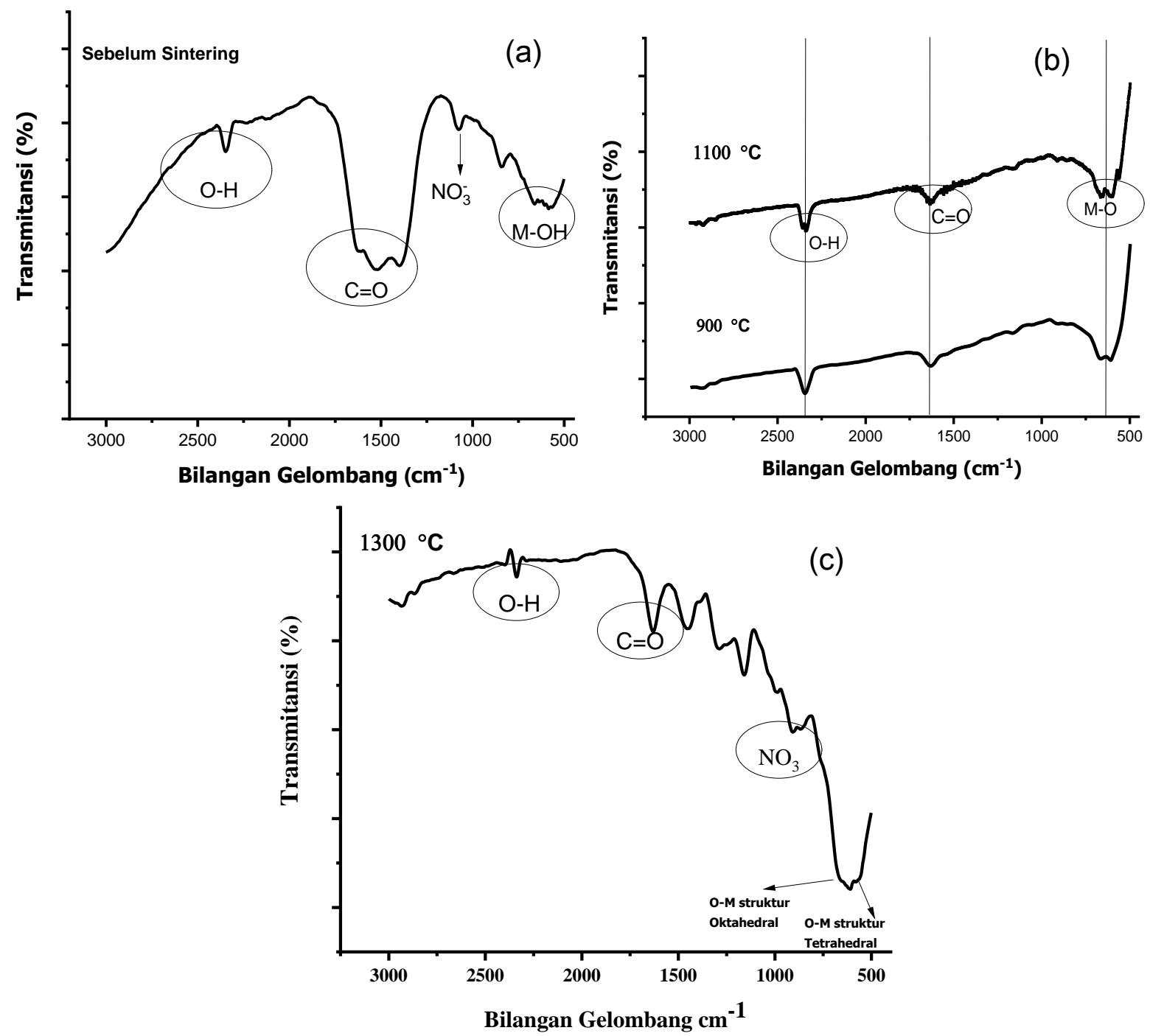

Gambar 5. Spektrum FTIR milik sampel dengan suhu sintering (a). sebelum sintering, (b). sintering suhu $900^{\circ} \mathrm{C}$ dan $1100^{\circ} \mathrm{C}$ dan (c) sintering suhu $1300^{\circ} \mathrm{C}$ 


\section{Analisis Morfologi dan Mikrostruktur}

Morfologi dan struktur mikro partikel untuk sampel dengan variasi suhu sintering ditampilkan pada Gambar 5. Dari gambar telihat perubahan bentuk dan ukuran partikel dari sampel yang telah dibuat. Pada gambar 5(a) dan 5(b), nampak bahwa sampel tidak memiliki ukuran partikel yang seragam dan kedua sampel memiliki tingkat aglomerasi yang tinggi. Hal ini kemungkinan besar disebabkan oleh adanya fasa pengotor milik fasa $\mathrm{YFeO}_{3}$ selain kehadiran fasa utama $\mathrm{Y}_{3} \mathrm{Fe}_{5} \mathrm{O}_{12}$. Pada sampel $\mathrm{T}=1300^{\circ} \mathrm{C}$ seperti yang ditampilkan pada Gambar 5(c), terlihat bahwa sampel memiliki distribusi ukuran partikel yang seragam tanpa ada perubahan ukuran partikel yang signifikan akibat suhu sintering, ukuran partikel berkisar antara 1 2 $\mu \mathrm{m}$. Hal ini tentu saja bersesuaian dengan hasil analisa XRD yang menyatakan bahwa fasa tunggal terbentuk pada suhu $1300{ }^{\circ} \mathrm{C}$ sehingga ukuran partikel memiliki tingkat homogenitas yang tinggi. Data ini menunjukan bahwa $\mathrm{Y}_{3} \mathrm{Fe}_{5} \mathrm{O}_{12}$ dapat disintesis dengan baik dengan metode sol-gel auto combustion dengan suhu optimum sintering pada suhu 1300 ${ }^{\circ} \mathrm{C}$.
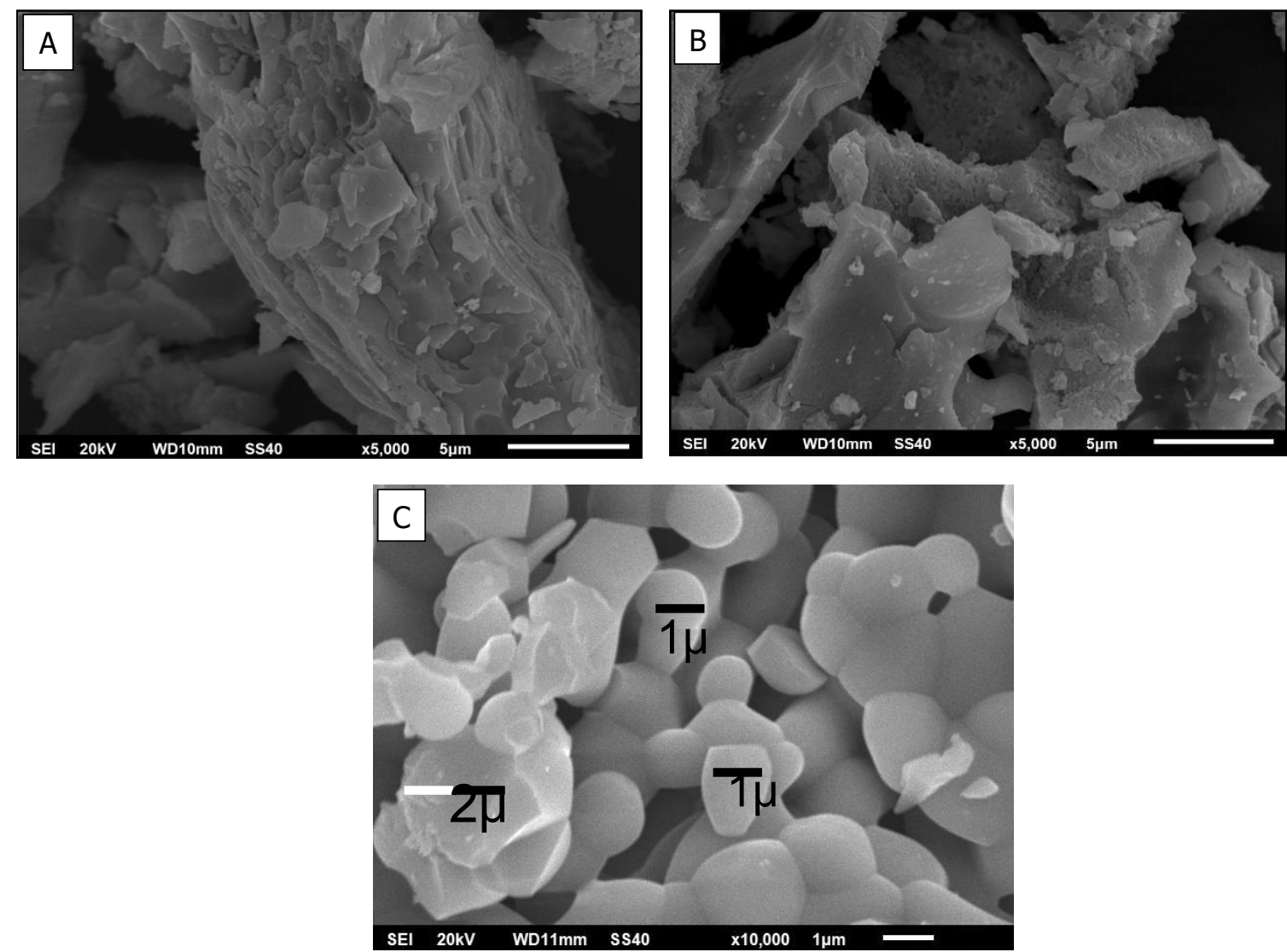

Gambar 6. Foto SEM untuk sampel dengan suhu sintering (a) $900^{\circ} \mathrm{C}$, (b) $1100^{\circ} \mathrm{C}$, dan (c) $1300^{\circ} \mathrm{C}$.

Untuk menentukan parameter kemagnetikan bahan seperti magnetisasi saturasi $\left(\mathrm{M}_{\mathrm{s}}\right)$ dan medan koersivitas $\left(\mathrm{H}_{\mathrm{c}}\right)$ pada seluruh sampel, seluruh sampel dikarakterisasi menggunakan vibrating sample magnetometer (VSM) dengan medan magnetik eksternal maksimal 1T. Hasil karakterisasi sifat magnetik bahan ditampilkan dalam bentuk grafik kurva histeresis (M-H) pada Gambar 6 sedangkan data parameter sifat magnetik ditampilkan pada tabel 2. Berdasarkan data yang dihasilkan, dapat diketahui bahwa perbedaan suhu sintering berpengaruh terhadap hasil parameter sifat magnetik yang dihasilkan. Sampel dengan suhu 
Tabel 2. Parameter sifat magnetik sampel dengan suhu sintering $900^{\circ} \mathrm{C}, 1100^{\circ} \mathrm{C}$, dan $1300^{\circ} \mathrm{C}$.

\begin{tabular}{ccc}
\hline Sampel & $\mathbf{M}_{\mathbf{s}}(\mathbf{e m u} / \mathbf{g})$ & $\mathbf{H}_{\mathbf{c}}\left(\mathbf{O}_{\mathbf{e}}\right)$ \\
\hline $\mathrm{Y}_{3} \mathrm{Fe}_{5} \mathrm{O}_{12}\left(900^{\circ} \mathrm{C}\right)$ & 19.59 & 17,25 \\
\hline $\mathrm{Y}_{3} \mathrm{Fe}_{5} \mathrm{O}_{12}\left(1100^{\circ} \mathrm{C}\right)$ & 19.69 & 16.27 \\
\hline $\mathrm{Y}_{3} \mathrm{Fe}_{5} \mathrm{O}_{12}\left(1300^{\circ} \mathrm{C}\right)$ & 20.75 & 9,30 \\
\hline
\end{tabular}

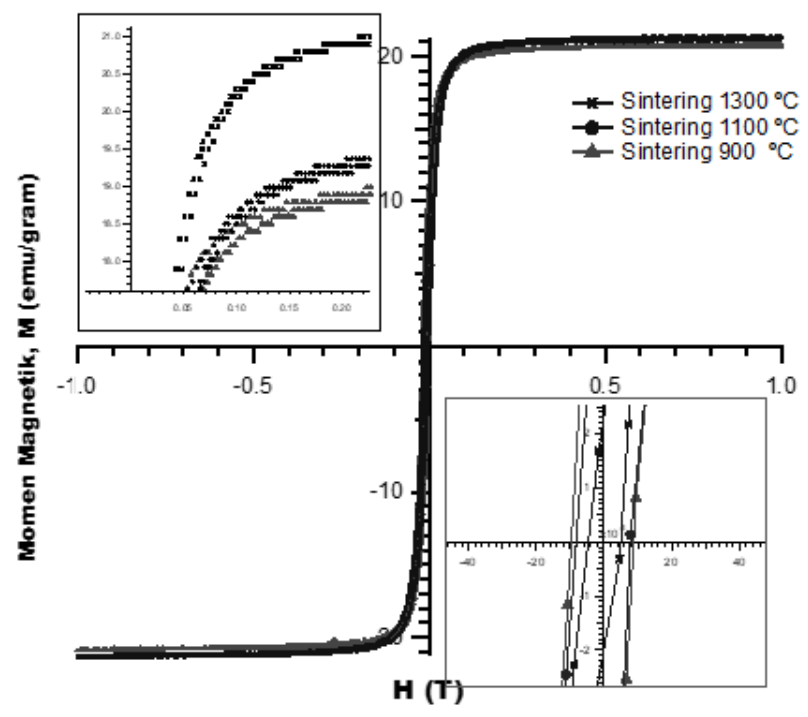

Gambar 7. Kurva hysteresis $\mathrm{Y}_{3} \mathrm{Fe}_{5} \mathrm{O}_{12}$ dengan variasi suhu sintering

sintering paling rendah $\left(\mathrm{T}=1100^{\circ} \mathrm{C}\right)$ memiliki nilai saturasi magnetisasi paling rendah sebesar $19.59 \mathrm{emu} / \mathrm{g}$ sedangkan sampel dengan suhu sintering tertinggi $\left(T=1300^{\circ} \mathrm{C}\right)$ memiliki nilai saturasi magnetisasi paling tinggi sebesar $20.75 \mathrm{emu} / \mathrm{g}$. Perubahan nilai saturasi magnetisasi disebabkan oleh kehadiran fasa garnet $\mathrm{Y}_{3} \mathrm{Fe}_{5} \mathrm{O}_{12}$ yang semakin besar seiring dengan kenaikan suhu sintering, dimana dapat kita ketahui pada tabel 1 bahwa fraksi berat fasa $\mathrm{Y}_{3} \mathrm{Fe}_{5} \mathrm{O}_{12}$ meningkat dari $68 \%\left(\mathrm{~T}=1100^{\circ} \mathrm{C}\right)$ menjadi $100 \%\left(\mathrm{~T}=1300^{\circ} \mathrm{C}\right)$. Faktor lain yang menyebabkan nilai saturasi magnetisasi pada sampel $\mathrm{T}=1100^{\circ} \mathrm{C}$ dan $1200^{\circ} \mathrm{C}$ adalah fasa pengotor $\mathrm{YFeO}_{3} . \mathrm{YFeO}_{3}$ merupakan material oksida dengan sistem kristal ortorombik-perovskit diketahui memiliki sifat feromagnetik namun dengan nilai saturasi magnetik yang rendah, sehingga hal ini menjadikan nilai saturasi magnetisasi menjadi lebih rendah dibandingkan pada sampel $\mathrm{T}=1300^{\circ} \mathrm{C}$.

\section{KESIMPULAN}

Pada penelitian ini, telah berhasil disintesis material $\mathrm{Y}_{3} \mathrm{Fe}_{5} \mathrm{O}_{12}$ menggunakan metode sol-gel auto combustion dengan perlakuan suhu sintering yang berbeda yaitu $900^{\circ} \mathrm{C}$, $1100^{\circ} \mathrm{C}$, dan $1300^{\circ} \mathrm{C}$. Telah diketahui bahwa proses perubahan fasa $\mathrm{YFeO}_{3}$ menjadi fasa garnet $\mathrm{Y}_{3} \mathrm{Fe}_{5} \mathrm{O}_{12}$ terjadi pada suhu di atas $900^{\circ} \mathrm{C}$ yang ditandai dengan terbentuknya puncak eksotermis pada kurva DTA-TGA, proses perubahan menjadi material garnet ini menjadi sempurna pada suhu di atas $1200^{\circ} \mathrm{C}$. Hal ini terkonfirmasi dengan hasil refinement pola difraksi sampel dengan variasi suhu sintering dimana sampel dengan suhu $\mathrm{T}=1300^{\circ} \mathrm{C}$ 
hanya terdiri dari 1 fasa penyusun yakni fasa garnet $\mathrm{Y}_{3} \mathrm{Fe}_{5} \mathrm{O}_{12}$, sedangkan sintesis dengan suhu sintering pada $900^{\circ} \mathrm{C}$ dan $1100^{\circ} \mathrm{C}$ masih mengandung fasa pengotor lain milik $\mathrm{YFeO}_{3}$. Pita serapan hasil karakterisasi FT-IR pada posisi bilangan gelombang $610 \mathrm{~cm}^{-1}$ dan $765 \mathrm{~cm}^{-1}$ merupakan mode khas yang dimiliki oleh struktur $\mathrm{Y}_{3} \mathrm{Fe}_{5} \mathrm{O}_{12}$. Selain fasa tunggal yang terbentuk, homogenitas ukuran partikel dan distribusi ukuran partikel yang merata juga berhasil dicapai pada sampel dengan suhu sintering $T=1300^{\circ} \mathrm{C}$. Oleh sebab itu, sampel ini juga menunjukkan nilai saturasi magnetisasi paling tinggi dibandingkan sampel yang lain. Berdasarkan hasil penelitian yang dilakukan, suhu sintering $\mathrm{T}=1300{ }^{\circ} \mathrm{C}$ merupakan suhu optimum untuk proses sintesis bahan garnet.

\section{UCAPAN TERIMA KASIH}

Penelitian ini didukung oleh dana pembiayaan tesis tahun 2020 dari Lembaga Penjamin Dana Pendidikan (LPDP) Kementerian Keuangan RI.

\section{DAFTAR PUSTAKA}

Akhtar, M. N. et al. (2017) 'Structural and electromagnetic evaluations of YIG rare earth doped (Gd, Pr, Ho, Yb) nanoferrites for high frequency applications', Ceramics International, 43(18), pp. 17032-17040. doi: 10.1016/j.ceramint.2017.09.115.

Aldbea, F. W., Ibrahim, N. B. and Yahya, M. (2014) 'Effect of adding aluminum ion on the structural, optical, electrical and magnetic properties of terbium doped yttrium iron garnet nanoparticles films prepared by sol-gel method', Applied Surface Science, 321, pp. 150-157. doi: 10.1016/j.apsusc.2014.10.019.

Ali, W. F. F. W. et al. (2013) 'Studies on the formation of yttrium iron garnet (YIG) through stoichiometry modification prepared by conventional solid-state method', Journal of the

European Ceramic Society, 33(7), pp. 1317-1324. doi: 10.1016/j.jeurceramsoc.2012.12.016.

Azis, R. S., Mustaffa, M. S. and Shahrani, N. M. M. (2018) 'Sintering Temperature Effect on Microstructure and Magnetic Evolution Properties with Nano- and Micrometer Grain Size in Ferrite Polycrystals', Sintering Technology - Method and Application, 3. doi: 10.5772/intechopen.78638.

Winatapura, D. S., Mulyawan, A., Adi, W. A. \& Yunasfi. Y. (2020) 'Synthesis, Structure, Magnetic and Absorption Properties of Nd Doped Y3Fe5012 Garnets Prepared by Mechanochemical Method', Key Engineering Materials, 855, pp. 52-57.

Fisli, A. et al. (2019) 'Iron oxide / titania composites for radar absorbing material ( RAM ) applications ( Compósitos de óxido de ferro / titânia para aplicações como', 65, pp. 470-476. doi: 10.1590/0366-69132019653752728.

Mahendraprabhu, K. and Elumalai, P. (2014) 'Influence of citric acid on formation of Ni/NiO nanocomposite by sol-gel synthesis', Journal of Sol-Gel Science and Technology, 73(2), pp. 428-433. doi: 10.1007/s10971-014-3554-7.

Mashadi, Yunasfi and Mulyawan, A. (2018) 'Microwave absorption study of manganese ferrite in $\mathrm{x}$-band range prepared by solid state reaction method', Jurnal Teknologi, 80(2), pp. 147-151. doi: 10.11113/jt.v80.10773.

Mathur, S. et al. (2005) 'Low-temperature synthesis and characterization of yttrium-gallium garnet Y3Ga5O12 (YGG)', Materials Research Bulletin, 40(3), pp. 439-446. doi: 10.1016/j.materresbull.2004.12.002.

Shahrani, N. M. et al. (2016) 'Effect of variation sintering temperature on magnetic permeability and grain sizes of $\mathrm{Y} 3 \mathrm{Fe} 5 \mathrm{O} 12$ via mechanical alloying technique', Materials Science Forum, 846(January), pp. 395-402. doi: 10.4028/www.scientific.net/MSF.846.395.

Musa, M. A. et al. (2017) 'Structural and magnetic properties of yttrium iron garnet (YIG) 
and yttrium aluminum iron garnet (YAIG) nanoferrite via sol-gel synthesis', Results in Physics, 7, pp. 1135-1142. doi: 10.1016/j.rinp.2017.02.038.

Nimbore, S. R. et al. (2006) 'Magnetic and electrical properties of lanthanum substituted yttrium iron garnets', Journal of Materials Science, 41(19), pp. 6460-6464. doi: 10.1007/s10853-006-0365-4.

Parashar, M., Shukla, V. K. and Singh, R. (2020) 'Metal oxides nanoparticles via sol-gel method: a review on synthesis, characterization and applications', Journal of Materials Science: Materials in Electronics, 31(5), pp. 3729-3749. doi: 10.1007/s10854-02002994-8.

Rane, A. V. et al. (2018) Methods for Synthesis of Nanoparticles and Fabrication of Nanocomposites, Synthesis of Inorganic Nanomaterials. Elsevier Ltd. doi: 10.1016/b978-0-08-101975-7.00005-1.

Ristić, M. et al. (2003) 'Influence of synthesis procedure on the YIG formation', Materials Letters, 57(16-17), pp. 2584-2590. doi: 10.1016/S0167-577X(02)01315-0.

Sharma, V. and Kuanr, B. K. (2018) 'Magnetic and crystallographic properties of rare-earth substituted yttrium-iron garnet', Journal of Alloys and Compounds, 748, pp. 591-600. doi: 10.1016/j.jallcom.2018.03.086.

Simonenko, N. P. et al. (2017) 'Sol-gel synthesis of iron yttrium garnet Y3Fe5O12 using metal acetylacetonates', Russian Journal of Inorganic Chemistry, 62(9), pp. 11351140. doi: 10.1134/S0036023617090145.

Yehia, M., Ismail, S. M. and Hashhash, A. (2014) 'Structural and magnetic studies of rareearth substituted nickel ferrites', Journal of Superconductivity and Novel Magnetism, 27(3), pp. 771-774. doi: 10.1007/s10948-013-2340-z.

Yunasfi, Y., Mashadi, M. and Mulyawan, A. (2017) 'SINTESIS BAHAN ABSORBER GELOMBANG MIKRO Ni(1,5-x)LaxFe1,504 DENGAN METODE SOL-GEL', Jurnal Sains Materi Indonesia, 19(1), p. 19. doi: 10.17146/jsmi.2017.19.1.4131.

Lau, Z. Y., Lee, H. S. and H. G. B. (2019) 'Experimental Study of Electromagnetic-Assisted Rare-Earth Doped Yttrium Iron Garnet (YIG) Nanofluids on Wettability and Interfacial Tension Alteration', Energies, 12(3806). 